\title{
Pengaruh Kombinasi Silika dan Asam Humat terhadap Ketersediaan Nitrogen dan Pertumbuhan Tanaman Padi pada Tanah Berpasir
}

\author{
Rusyla Dwi Rahayu, Wanti Mindari, Moch. Arifin \\ Program Studi Agroteknologi, Fakultas Pertanian, \\ Universitas Pembangunan Nasional "Veteran” Jawa Timur \\ Korespondensi: wanti_m@upnjatim.ac.id
}

\begin{abstract}
Sandy soils have high macropores and low nutrient availability. This condition is caused by the soil matrix which has no negative charge, so that nutrients are easily lost due to washing. Nitrogen loss has been reported to reduce rice production by 6.10\%. The research aims to examine the application of humic acid and silica to increase the availability of nitrogen nutrients. Humic acid from compost and silica from rice husk is expected to increase the negative charge of the soil so that can adsorbnutrient ions such as nitrogen. The research was carried out from March to September 2021 in the greenhouse and laboratory of the Faculty of Agriculture, National Development University "Veteran" East Java. The research was structured using a factorial Completely Randomized Design (CRD). The first factor is silica dose with a level of 0 ton/ha, 0.5 ton/ha, 1 ton/ha, and 1.5 ton/ha. The second factor is the dose of humic acid with a level of $0 \mathrm{~kg} / \mathrm{ha}, 20 \mathrm{~kg} / \mathrm{ha}, 40 \mathrm{~kg} / \mathrm{ha}$, and $60 \mathrm{~kg} / \mathrm{ha}$. Observation parameters include the availability of $\mathrm{N}$ in the soil, the growth of rice plants which include plant length and the number of tillers. The results showed that the combination of humic acid and silica didn't significantly affect plant length and number of tillers, but had a significant effect on nitrogen availability. The best dose of the combination of silica with humic acid on nitrogen availability in sandy soils is S2H3 (Silica 1 ton/ha with humic acid $60 \mathrm{~kg} / \mathrm{ha}$ ).
\end{abstract}

Keywords: humic acid, silica, rice, Nitrogen

\section{PENDAHULUAN}

Tanah berpasir memiliki pori dominan makro, porositas yang tinggi dan kemampuan menahan air serta hara yang rendah sehingga unsur hara yang ada di dalamnya menjadi mudah hilang (Lumbanraja dan Harahap, 2015). Nitrogen di dalam tanah bersifat mudah bergerak sehingga keberadaannya cepat berubah dan mudah hilang. Kehilangan nitrogen disebabkan karena volatilisasi, denitrifikasi, pencucian (leaching), erosi, dan hilang bersama panen (Vermoesen et al., 1993). Nitrogen dibutuhkan tanaman dalam jumlah besar pada masa vegetatif tanaman (Patti dkk., 2013), Kehilangan nitrogen menyebabkan serapan hara tersebut kurang optimal sehingga menurunkan produksi padi (Liu et al., 2019).

Berbagai upaya untuk meningkatkan ketersediaan $\mathrm{N}$ telah dilakukan, diantaranya dengan pemberian pembenah tanah dan pupuk N. Pemberian urea dosis tepat bisa mengatasi permasalahan di atas. Pemupukan $\mathrm{N}$ berbasis pengamatan dengan bagan warna daun (BWD) lebih efisien daripada pemupukan secara konvensional yang terjadwal, karena bisa menghemat pupuk N 10-53\% (Wahid, 2003). Pembenah tanah berpengaruh sangat nyata terhadap nitrogen tanah karena mampu mengikat nitrogen sehingga menjadi tersedia dan tidak mudah mengalami leaching (Sari dan Arifandi, 2019).

Asam humat dan silika berpotensi untuk meningkatkan kemampuan jerap $\mathrm{NH}_{4}{ }^{+}$dan $\mathrm{NO}_{3}$-(Hermanto dkk., 2013). Asam humat merupakan asam organik penyusun substansi humus yang meningkatkan kemampuan tanah dalam mengikat, mengkhelat, dan menjerap nutrisi sehingga mengurangi kehilangan unsur hara akibat leaching (Ali dan Mindari, 2016). Kemampuan tersebut tidak terlepas dari keberadaan gugus-gugus aktif yang dimiliki asam humat (Suntari et al., 2013; Yu et al., 2019) dan kapasitas tukar kation yang tinggi untuk menjerap unsur hara nitrogen, fosfor dan kalium sehingga meningkatkan serapan, kualitas serta produksi tanaman padi (Mahmood et al., 2019). Pemberian asam 
humat dan pupuk NPK dapat meningkatkan serapan unsur hara terutama nitrogen pada tanaman padi (Nuraini dan Zahro, 2020).

Silika merupakan unsur hara yang dinilai mampu meningkatkan ketersediaan hara, kapasitas tukar kation (KTK), serapan unsur hara dan mengurangi kehilangan hara (Kristanto, 2018; Alsaeedi et al., 2019). Silika juga dapat meningkatkan pertumbuhan tanaman dan mempengaruhi translokasi nutrisi dari akar menuju pucuk tanaman (Gregeret al, 2018; Singh et al., 2005).Silika yang diperoleh dari ektraksi abu sekam padi mampu digunakan sebagai adsorben yang baik (Peres et al., 2018) dan mampu meningkatkan produktivitas tanaman padi.

Berdasarkan potensi yang dimiliki oleh asam humat dan silika, maka diperlukan penelitian lanjut untuk meningkatkan ketersediaan nitrogen pada tanah berpasir serta partumbuhan tanaman tanaman padi yang optimal.

\section{METODOLOGI}

Penelitian dilaksanakan pada bulan Maret 2021 sampai dengan September 2021 di greenhouse dan laboratorium sumber daya lahan Fakultas Pertanian Universitas Pembangunan Nasional "Veteran” Jawa Timur. Penelitian disusun menggunakan Rancangan Acak Lengkap (RAL) faktorial. Faktor pertama yaitu pupuk silika dalam bentuk cair yang terdiri atas 4 level dosis, yaitu: level 0 ton ha-1 (S0), 0,5 ton ha-1 (S1), 1 ton ha-1 (S2), dan 1,5 ton $\mathrm{ha}^{-1}$ (S3). Faktor kedua yaitu 4 dosis asam humat cair $(\mathrm{H})$ dengan level $0 \mathrm{~kg} \mathrm{ha}^{-1}(\mathrm{H} 0), 20$ $\mathrm{kg} \mathrm{ha}^{-1}$ (H1), $40 \mathrm{~kg} \mathrm{ha}^{-1}$ (H2), dan $60 \mathrm{~kg} \mathrm{ha}^{-1}$ (H3). Total perlakuan kombinasi 16 yang masing-masing diulang 3 kali.

Penelitian dilaksanakan dengan beberapa tahap yaitu persiapan, aplikasi pembenah tanah dan pemberian pupuk dasar NPK, penanaman, pemeliharaan tanaman, dan panen. Tahap persiapan meliputi ekstraksi pupuk silika dan asam humat. Ekstrak silika (dalam bentuk cair) ini berasal dari abu sekam padi, mengacu kepada Nwite (2019). Asam humat diekstrak dari kompos dengan menggunakan metode Stevenson (1994) dan ekstraksi silika dari sekam padi dengan menggunakan metode ekstraksi basa (Agung dkk., 2013).

Penyiapan media tanam dari tanah yang diambil dari Desa Mekikis Kecamatan Purwoasri, Kabupaten Kediri pada kedalaman 0- $20 \mathrm{~cm}$. Berdasarkan hasil analisi awal, tekstur tanah termasuk ke dalam kelas lempung berpasir, dan bereaksi masam (Tabel 1). Tanah sebanyak $7 \mathrm{~kg}$ dimasukkan ke setiap pot. Pot yang telah berisi media tanam kemudian diberikan asam humat dan silika dengan kombinasi dosis sesuai rancangan percobaan yang sudah ditentukan.

Tabel 1 Karakteristik Sampel Tanah pewakil

\begin{tabular}{|c|c|c|c|c|}
\hline No. & Parameter & Satuan & Hasil & Kriteria* \\
\hline 1 & $\mathrm{pH} \mathrm{H}_{2} \mathrm{O}$ & - & 5,73 & $\begin{array}{c}\text { Agak } \\
\text { masam }\end{array}$ \\
\hline 2 & C-Organik & $\%$ & 0,79 & $\begin{array}{l}\text { Sangat } \\
\text { rendah }\end{array}$ \\
\hline 3 & N-Total & $\%$ & 0,1 & Rendah \\
\hline 4 & $\mathrm{P}_{2} \mathrm{O}_{5}$ & ppm & 59,56 & $\begin{array}{l}\text { Sangat } \\
\text { tinggi }\end{array}$ \\
\hline 5 & $\mathrm{~K}_{\mathrm{dd}}$ & $\mathrm{cmol} / \mathrm{kg}$ & 6,26 & $\begin{array}{l}\text { Sangat } \\
\text { tinggi }\end{array}$ \\
\hline 6 & KTK & $\mathrm{cmol} / \mathrm{kg}$ & 13,89 & Rendah \\
\hline 7 & Amonium & ppm & 251,46 & - \\
\hline 8 & Nitrat & ppm & 74,76 & - \\
\hline \multirow[t]{4}{*}{9} & Tekstur & & & \\
\hline & - Pasir & $\%$ & 55 & Lempung \\
\hline & - Debu & $\%$ & 32 & Berpasir \\
\hline & - Liat & $\%$ & 13 & \\
\hline
\end{tabular}

Sebelum aplikasi pembenah tanah telah diketahui berat jenisnya (B) untuk memudahkan perhitungan aplikasi (Tabel 2). Pemberian pembenah tanah dilakukan 5 hari sebelum tanam bibit tanaman padi. Proses inkubasi ditujukan untuk meratakan sebaran pembenah tanah.

Tahap selanjutnya yakni penanaman hingga panen. Bibit tanaman padi yang digunakan yaitu varietas cibogo yang telah 
berumur 17 hari. Pupuk diberikan satu kali pada saat awal tanam padi dengan dosis $260 \mathrm{~kg}$ urea/ha, $61 \mathrm{~kg} \mathrm{SP-36/ha,} \mathrm{dan} 69 \mathrm{~kg} \mathrm{KCl} / \mathrm{ha}$ (Bijay et al., 1991). Pemeliharaan tanaman meliputi penyiraman, penyiangan, dan pengendalian organisme pengganggu tanaman.

Tabel 2 Nilai Berat Jenis Pembenah Tanah

\begin{tabular}{cccc}
\hline Parameter & Satuan & $\begin{array}{c}\text { Asam } \\
\text { Humat }\end{array}$ & Silika \\
\hline Berat Jenis & $\mathrm{g} / \mathrm{cm}^{3}$ & 0.96 & 0.96 \\
\hline
\end{tabular}

Parameter yang diamati yaitu nitrogen tersedia $\left(\mathrm{NH}_{4}{ }^{+}\right.$dan $\left.\mathrm{NO}_{3}{ }^{-}\right)$, tinggi tanaman, dan jumlah anakan. Pengambilan sampel tanah untuk parameter nitrogen tersedia dilakukan pada 0 HST, 15 HST, 60 HST, dan 90 HST. Pengamatan parameter tinggi tanaman dan jumlah anakan dilakukan seminggu sekali. Analisa kandungan $\mathrm{NH}_{4}{ }^{+}$dan $\mathrm{NO}_{3}^{-}$secara laboratorium menggunakan metode destilasi titrimeteri (Balittanah, 2009).

Data yang diperoleh dianalisis keragamannya (ANOVA) dengan uji $\mathrm{F}$ pada tingkat kesalahan 5\%, untuk mengetahui pengaruh dari perlakuan yang diaplikasikan. Jika terdapat perbedaan nyata dari perlakuan maka dilakukan uji lanjut Beda Nyata Jujur (BNJ) pada tingkat kesalahan $5 \%$.

\section{HASIL DAN PEMBAHASAN}

\subsection{Ketersediaan Nitrogen}

Nitrogen (N) merupakan unsur hara penting bagi tanaman terutama pada masa pertumbuhan tanaman. Nitrogen tersedia merupakan nitrogen yang berada di dalam tanah dan siap untuk dimanfaatkan tanaman dalam bentuk $\mathrm{NH}_{4}{ }^{+}$dan $\mathrm{NO}_{3}{ }^{-}$. Hasil analisis statistik-pada Gambar 1 menunjukkan bahwa pemberian kombinasi silika dan asam humat memberikan pengaruh nyata terhadap ketersediaan nitrogen $\left(\mathrm{NH}_{4}{ }^{+}\right.$dan $\left.\mathrm{NO}_{3}^{-}\right)$pada umur tanaman padi 60 HST dan 90 HST, sedangkan ketersediaan nitrogen pada umur padi 0 HST dan 15 HST tidak berbeda nyata. Hal tersebut terjadi karena $\mathrm{N}-\mathrm{NH}_{4}+$ dan $\mathrm{N}-\mathrm{NO}_{3}-$ yang dijerap silika maupun asam humat tanah dan dilepaskan pelan-pelan ke larutan tanah sehingga mampu mengurangi kehilangan hara pada tanah berpasir (Kristanto, 2018).

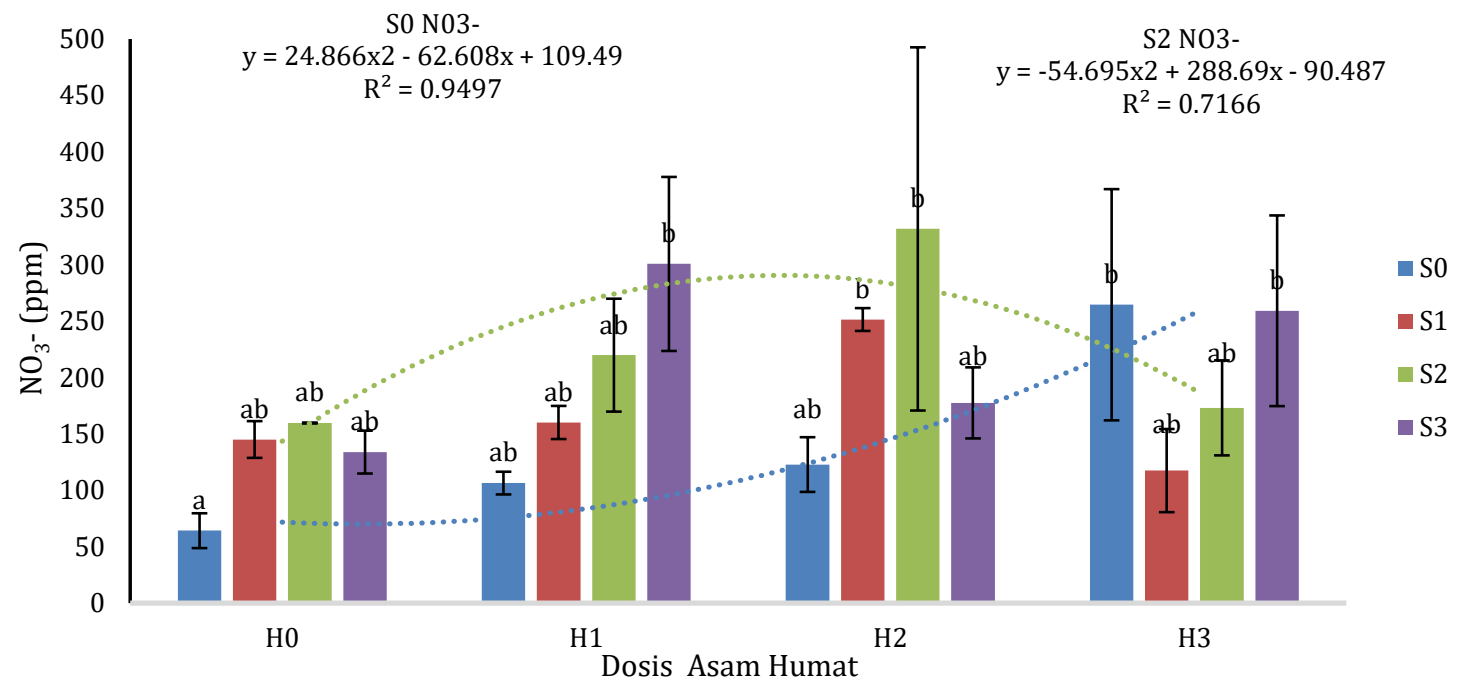

Gambar 1 Pengaruh Kombinasi Asam Humat dan Silika terhadap $\mathrm{NO}_{3}{ }^{-}$pada $60 \mathrm{HST}$

Hubungan yang erat antara asam humat dan silika terhadap kadar $\mathrm{NO}_{3}$ - dapat terlihat pada umur padi 60 HST. Pada perlakuan S0, nilai $\mathrm{R}^{2}$ Asam humat sebesar 0,9497 yang berarti $95 \%$ nitrat tanah dipengaruhi asam humat. Pada perlakuan S2 (dosis silikat 1,5 ton/ha) dan asam humat $20 \mathrm{~kg} / \mathrm{ha}$ enghasilkan kadar nitrat tertinggi, dengan nilai $\mathrm{R}^{2}$ 0,7166. 
Artinya $72 \%$ nilai nitrat tanah dipengaruhi asam humat. Ada kombinasi positif antara pemberian asam humat dan silikat dalam menjerap $\mathrm{N}$ tanah untuk dilepaskan secara perlahan lahan ke dalam larutan tanah.

Gambar 2 memperlihatkan hubungan antara asam humat dan silika terhadap kadar $\mathrm{NO}_{3}$ - tanah pada pertumbuhan tanaman padi 90 HST. Pada perlakuan S2 (silika 1 ton/ha), kadar nitrat tanah tertinggi berada pada perlakuan asam humat $\mathrm{H} 2(20 \mathrm{~kg} / \mathrm{ha})$.

Ketersediaan amonium tanah berkorelasi positif tinggi dengan perlakuan asam humat pada perakuan S2 dan S3. Nilai tertinggi terdapat pada perlakuan S2H3. Pad dosis S2, semakin banyak asam humat akan menyediakan amnium semakin banyak, namun hal ini tidak berlaku untuk S3.

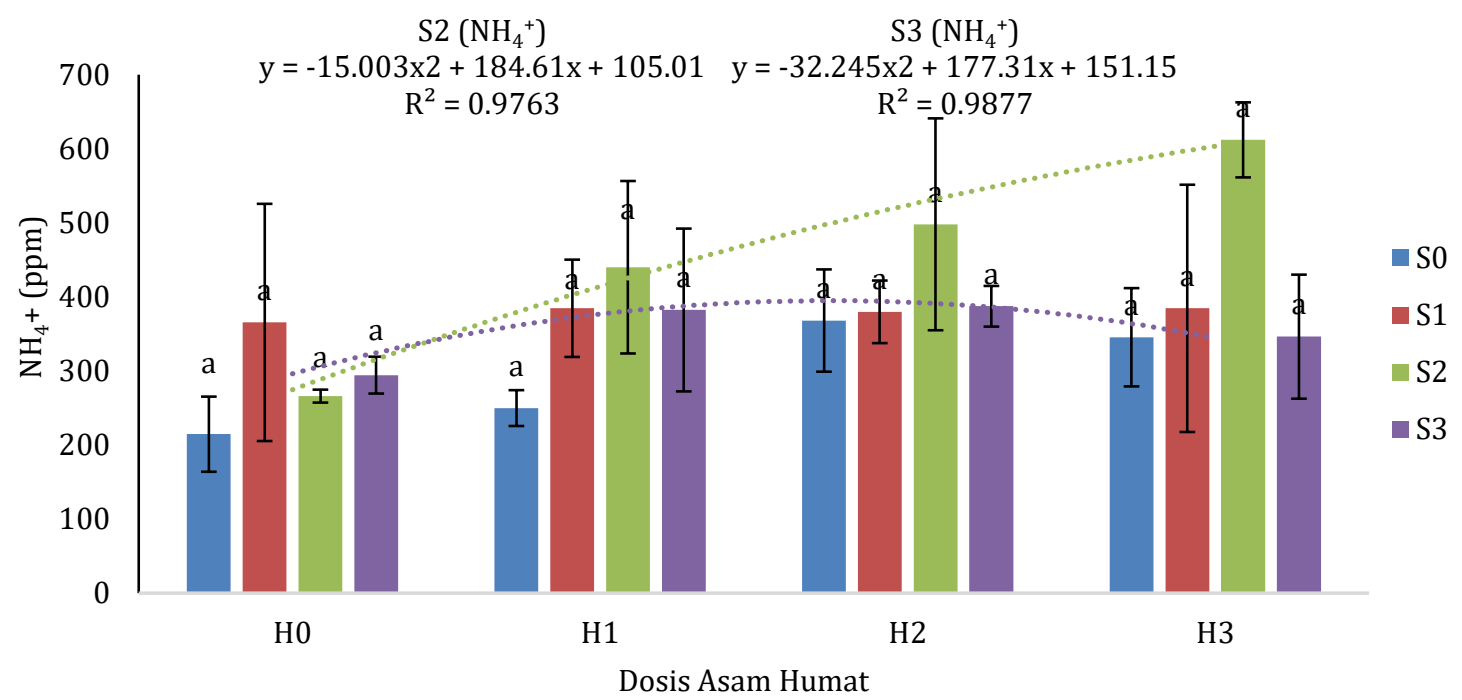

Gambar 2 Pengaruh Kombinasi Asam Humat dan Silika terhadap $\mathrm{NO}_{3}$ - pada $90 \mathrm{HST}$

Hubungan antara perlakuan asam humat dan silika terhadap kadar $\mathrm{NH}_{4}{ }^{+}$pada umur padi 60 HST disajikan pada Gambar 3. Perlakuan S3 berkorelasi tertinggi disbanding perlakuan lainnya, dengan nilai $\mathrm{R}^{2}$ 0,9877. Hal ini menunjukkan bahwa perlakuan S3 memiliki keeratan dengan setiap perlakuan asam humat. Kadar nitrat tertinggi berada pada perlakuan S2H3, namun dosis optimum NH4+ pada umur 60 HST berdasaran trendline S3 berada pada perlakuan S3H1 (silika 1,5 ton/ha dengan asam humat $20 \mathrm{~kg} / \mathrm{ha}$ ).

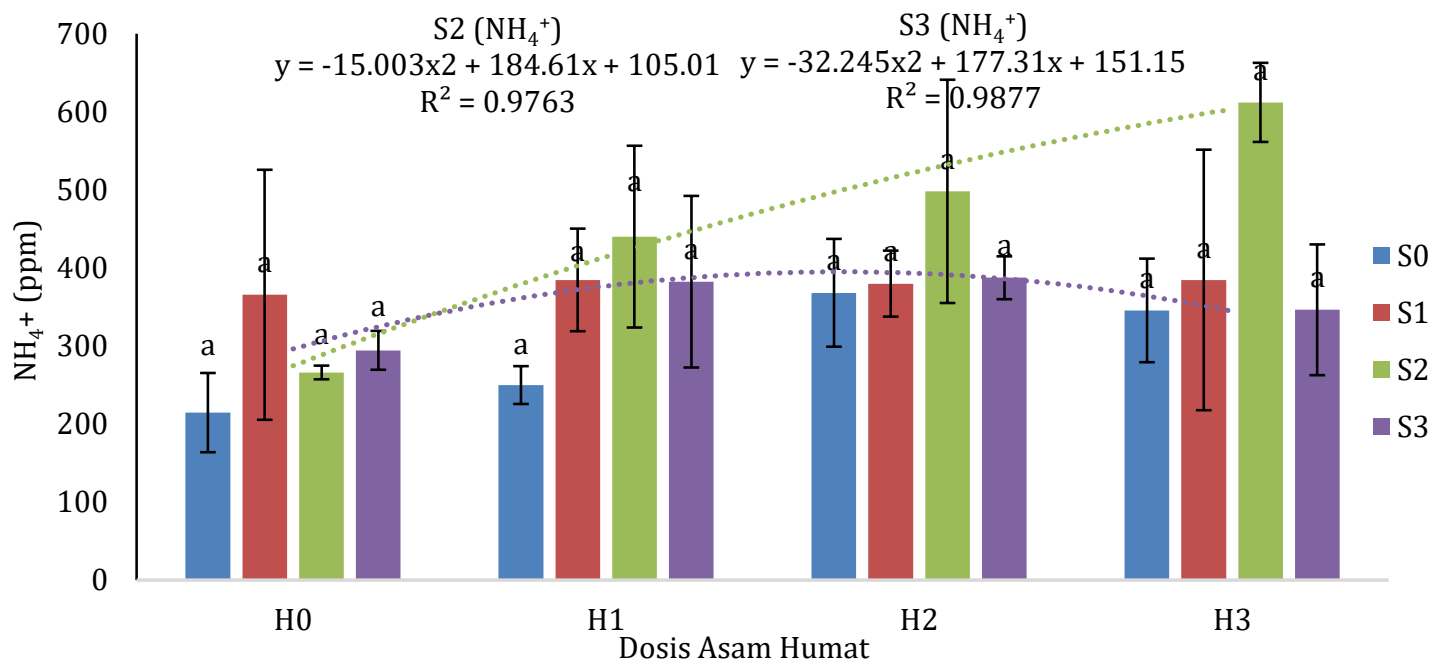

Gambar 3 Pengaruh Kombinasi Asam Humat dan Silika terhadap $\mathrm{NH}_{4}{ }^{+}$pada $60 \mathrm{HST}$ 
Perlakuan S0 memiliki hubungan yang sangat erat dengan asam humat untuk kadar $\mathrm{NH}_{4}{ }^{+}$pada umur padi $90 \mathrm{HST}$ sebesar 0.983 dibandingkan perlakuan siliki yang lain. Kadar nitrat tertinggi berada pada perlakuan S2H3, namun dosis optimum $\mathrm{NH} 4+$ pada umur 90 HST berdasaran trendline S0 berada pada perlakuan S2H1 (silika 1 ton/ha dengan asam humat $20 \mathrm{~kg} / \mathrm{ha}$ ).

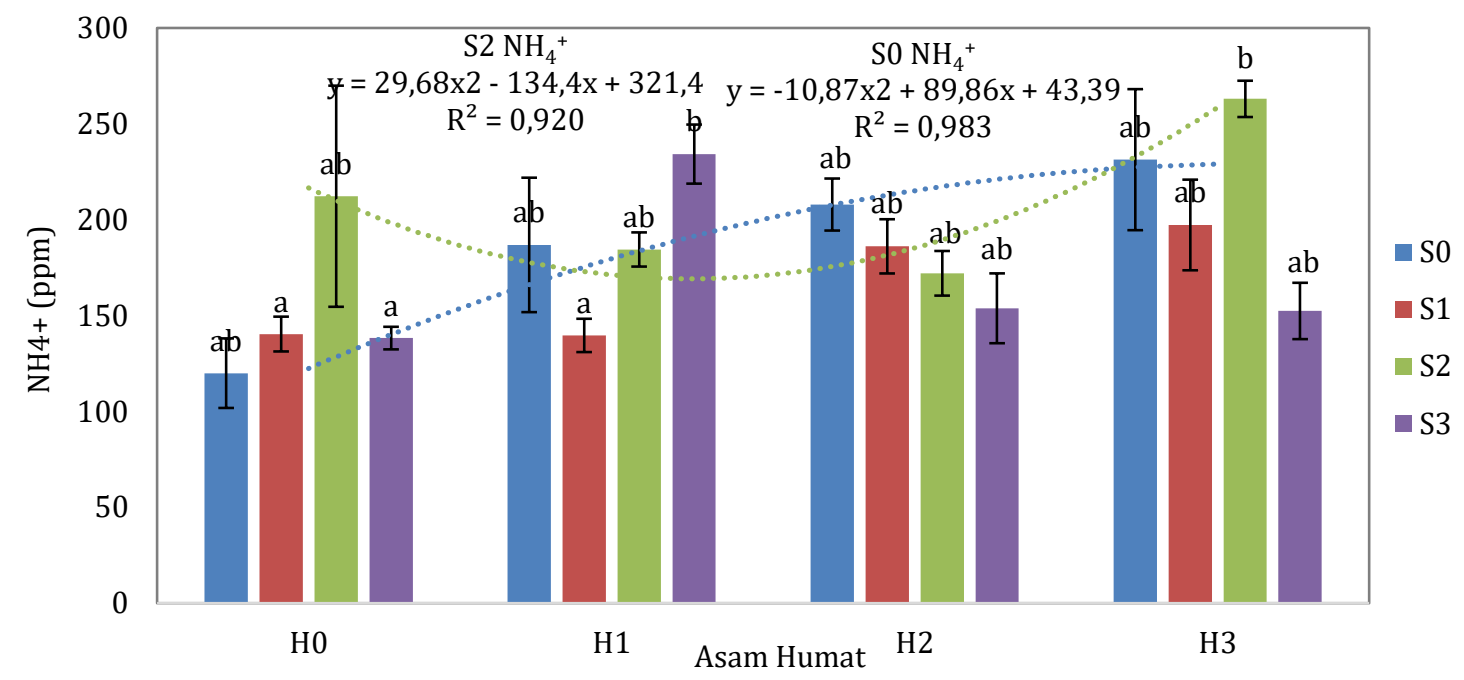

Gambar 4 Pengaruh Kombinasi Asam Humat dan Silika terhadap NH4+ pada 90 HST

Kadar $\mathrm{NO}_{3}$ - tertinggi didapatkan pada tanaman padi berumur 60 HST dan menurun pada umur 90 HST (Gambar 5). Hal ini karena hara tersebut telah dimanfaatkan tanaman untuk pengisian biji (Patty et al., 2013). Kadar $\mathrm{NO}_{3}$ - tertinggi pada perlakuan kombinasi $\mathbf{S}_{2} \mathbf{H}_{3}$ (Silika 1 ton/ha, Asam humat $60 \mathrm{~kg} / \mathrm{ha}$ ) sebesar 741,98 ppm. Dosis kombinasi ini dianggap optimum untuk meningkatkan ketersediaan $\mathrm{N}$-nitrat dibanding dosis lainnya.

Hasil analisa ketersediaan nitrogen (Gambar 5) tanaman padi pada tanaman umur 0 HST hingga 90 HST, menunjukkan bahwa kadar ammonium tanah lebih tinggi dibanding dengan kadar nitrat tanah. Kadar ammonium tanah yang tinggi dapat disebabkan karena pergerakan amonium lebih lambat dibandingkan dengan nitrat. Ammonium merupakan kation yang dapat teradsorbsi di permukaan koloid tanah, sehingga ketersediaan ammonium lebih tinggi dibandingkan dengan nitrat tanah yang senantiasa bebas larut di larutan tanah (Plhák, 2003). Tanah lempung berpasir dominan memiliki pori makro yang memudahkan ion dalam bentuk anion mudah bergerak ke lapisan lebih bawah atau tercuci (Kristanto, 2018).

Secara keseluruhan aplikasi silika 1 ton /ha dan asam humat 40 ton/ha sudah memberikan hasil baik terhadap ketersediaan $\mathrm{N}$ tanah. Ketersediaan Nitrogen $\left(\mathrm{NH}_{4}+\right.$ dan $\left.\mathrm{NO}_{3}\right)$ pada semua perlakuan meningkat. Hal ini menunjukkan bahwa $\mathrm{NH}_{4}{ }^{+}$maupun $\mathrm{NO}_{3}$ yang diikat oleh pembenah tanah sehingga mampu mengurangi kehilangan hara $\mathrm{N}$ dan tanaman padi dapat menyerap nitrogen dengan optimal. Gugus karboksilat dan fenolik pada asam humat dan gugus silanol dan siloksan pada silika dapat menjerap $\mathrm{NH}_{4}{ }^{+}$maupun $\mathrm{NO}_{3}{ }^{-}$ (Coasne et al, 2010; Sivakumar, 2007), dimana asam humat dan silika dapat menahan nitrogen dan mengurangi kehilangan hara yang diakibatkan oleh penguapan maupun pencucian. Kadar $\mathrm{NH}_{4}{ }^{+}$dan $\mathrm{NO}_{3}{ }^{-}$pada 90 HST mengalami penurunan dikarenakan nitrogen telah diserap tanaman padi (Patty et al., 2013). 


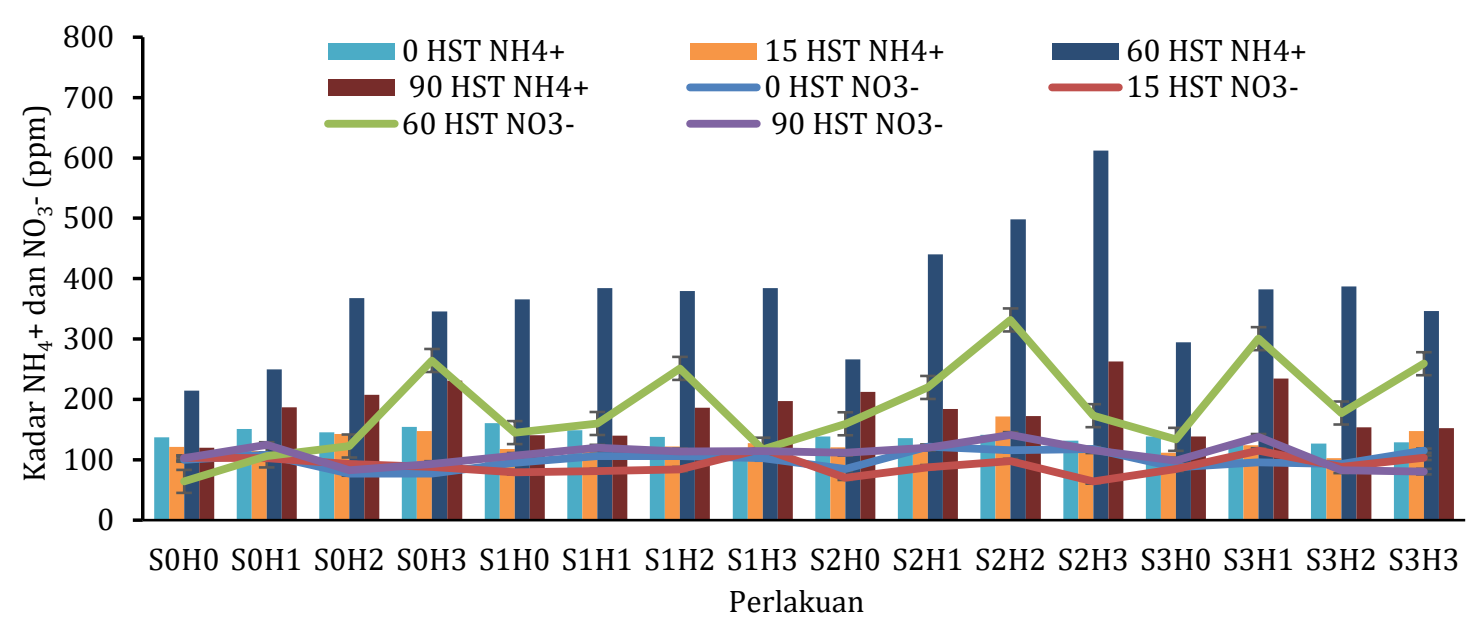

Gambar 5 Pengaruh Kombinasi Silika dengan Asam Humat terhadap $\mathrm{NH}_{4}^{+}$

\subsection{Tinggi Tanaman dan Jumlah Anakan Tanaman Padi}

Tanaman padi mengalami peningkatan tinggi tanaman dari 0 MST sampai dengan 8 MST untuk semua perlakuan (Gambar 6). Perlakuan yang memberikan dampak terbaik untuk tinggi tanaman padi yakni pada perlakuan S2H3 (Silika 1 ton/ha, Asam humat $60 \mathrm{~kg} / \mathrm{ha}$ ). Hal tersebut menunjukkan bahwa pemberian kombinasi asam humat dan silika mampu memberikan respon positif untuk tinggi tanaman padi. Senada dengan pendapat
Singh et al. (2005) yang mengungkapkan bahwa pemberian silika dapat meningkatkan pertumbuhan pada tanaman padi. Aplikasi asam humat juga mampu meningkatkan pertumbuhan tanaman padi (Nuraini dan Zahro, 2020).Tinggi tanaman setiap periode pertumbuhan akan berbeda-beda karena dipengaruhi faktor lingkungan dan juga faktor genetik, akan tetapi tinggi tanaman padi umumnya akan semakin tinggi dengan bertambahnya umur tanaman (Dobermann and Fairhust, 2000).

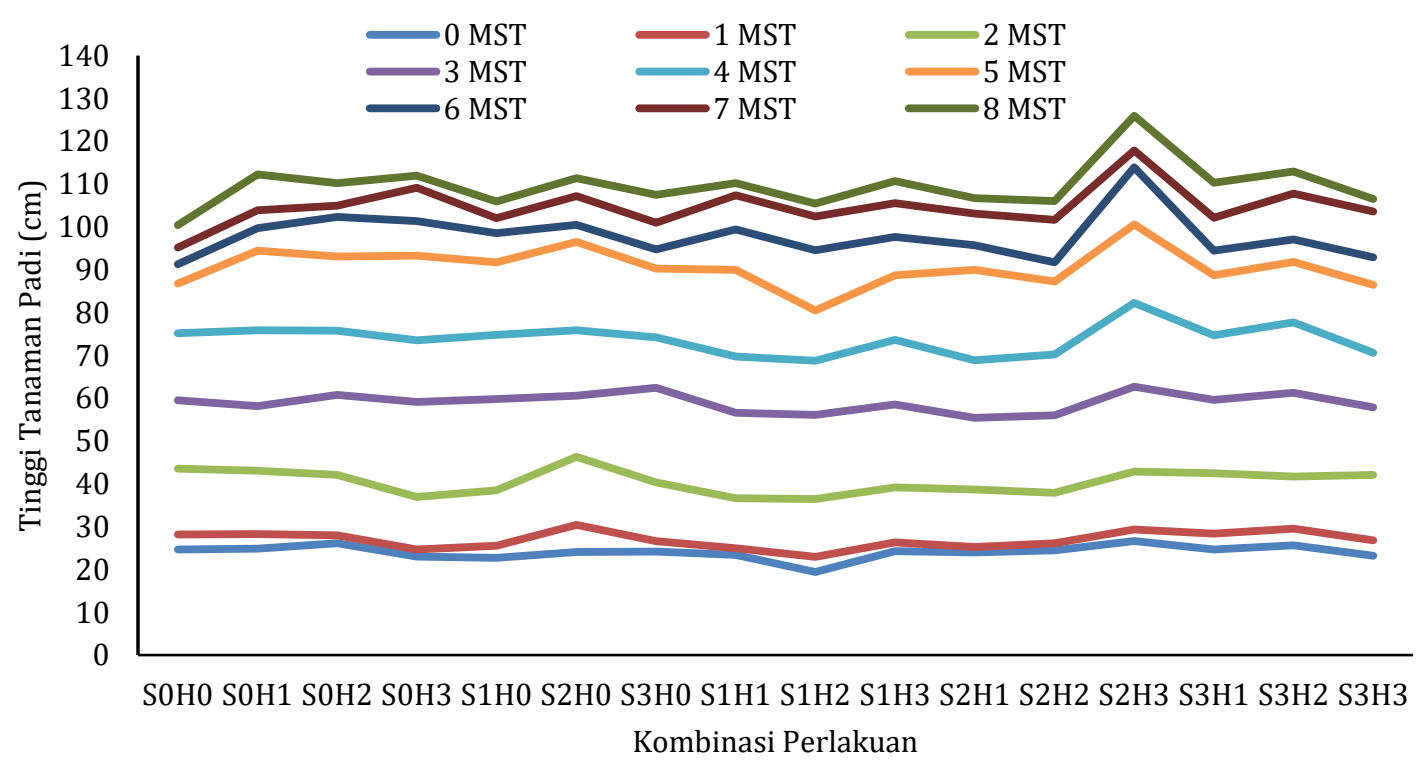

Gambar 6 Pengaruh Kombinasi Silika dan Asam Humat terhadap Tinggi Tanaman Padi

Unsur hara nitrogen berperan dalam meningkatkan jumlah anakan pada tanaman padi
(Kaya, 2018). Hasil penelitian menunjukkan bahwa kombinasi silika dengan asam humat 
berpengaruh nyata terhadap jumlah anakan hanya pada 2 MST dan terbanyak pada perlakuan $\mathrm{S}_{2} \mathrm{H}_{3}$ (Silika 1 ton/ha, Asam humat $60 \mathrm{~kg} / \mathrm{ha}$ ). Jumlah anakan pada tanaman padi hingga 8 MST meningkat meskipun antar perlakuan tidak berbeda nyata. Nilai tertinggi pada perlakuan dosis tertinggi, yaitu Silika 1,5 ton/ha, Asam humat $60 \mathrm{~kg} / \mathrm{ha}$ (Tabel 3).

Tabel 3 Hasil Analisis BNJ Jumlah Anakan Padi hingga 8 MST setelah Pemberian Asam Humat dan Silika pada Tanah Berpasir

\begin{tabular}{|c|c|c|c|c|c|c|c|c|c|}
\hline \multirow{2}{*}{ Perlakuan } & \multicolumn{9}{|c|}{ Jumlah Anakan Tanaman Padi per umur tanaman } \\
\hline & 0 MST & $1 \mathrm{MST}$ & $2 \mathrm{MST}$ & $3 \mathrm{MST}$ & $4 \mathrm{MST}$ & $5 \mathrm{MST}$ & $6 \mathrm{MST}$ & $7 \mathrm{MST}$ & $8 \mathrm{MST}$ \\
\hline SOHO & 3 & 3 & $4 \mathrm{ab}$ & 10 & 14 & 23 & 23 & 23 & 23 \\
\hline S0H1 & 3 & 3 & $3 \mathrm{a}$ & 8 & 12 & 22 & 24 & 24 & 25 \\
\hline $\mathrm{S} 0 \mathrm{H} 2$ & 3 & 3 & $4 \mathrm{ab}$ & 7 & 12 & 21 & 21 & 21 & 21 \\
\hline SOH3 & 3 & 3 & $3 a b$ & 6 & 10 & 17 & 19 & 20 & 20 \\
\hline S1H0 & 3 & 3 & $3 a$ & 6 & 10 & 18 & 21 & 20 & 20 \\
\hline $\mathrm{S} 2 \mathrm{H} 0$ & 3 & 3 & $4 a b$ & 8 & 13 & 22 & 23 & 23 & 23 \\
\hline S3H0 & 3 & 3 & $4 a b$ & 7 & 13 & 21 & 22 & 23 & 23 \\
\hline S1H1 & 3 & 3 & $3 \mathrm{a}$ & 8 & 11 & 21 & 22 & 23 & 23 \\
\hline $\mathrm{S} 1 \mathrm{H} 2$ & 3 & 3 & $3 a b$ & 7 & 9 & 19 & 21 & 22 & 22 \\
\hline S1H3 & 3 & 3 & $4 a b$ & 8 & 12 & 20 & 23 & 23 & 23 \\
\hline $\mathrm{S} 2 \mathrm{H} 1$ & 3 & 3 & $3 a b$ & 7 & 10 & 23 & 24 & 24 & 24 \\
\hline $\mathrm{S} 2 \mathrm{H} 2$ & 3 & 3 & $3 a$ & 7 & 10 & 20 & 21 & 21 & 21 \\
\hline $\mathrm{S} 2 \mathrm{H} 3$ & 3 & 3 & $5 b$ & 5 & 11 & 16 & 17 & 17 & 17 \\
\hline S3H1 & 3 & 3 & $4 a b$ & 10 & 13 & 22 & 23 & 24 & 24 \\
\hline $\mathrm{S} 3 \mathrm{H} 2$ & 3 & 3 & $3 a$ & 7 & 9 & 19 & 20 & 20 & 20 \\
\hline S3H3 & 3 & 3 & $3 a$ & 10 & 14 & 23 & 25 & 26 & 26 \\
\hline BNJ 5\% & tn & tn & 1,47 & tn & tn & tn & tn & tn & tn \\
\hline
\end{tabular}

Keterangan: tn: tidak berbeda nyata

Korelasi antara ketersediaan nitrogen di dalam tanah dengan jumlah anakan sangat rendah 17,03\% (Gambar 7). Hal ini menunjukkan bahwa nitrogen bukan satu-satunya faktor penentu jumlah anakan padi. Korelasi ketersediaan nitrogen dalam tanah dengan tinggi tanaman yakni sebesar 46,63\% (Gambar 8), hal ini menunjukkan bahwa $\mathrm{N}$ lebih berpengaruh terhadap tinggi tanaman dibandingka dengan jumlah anakan. Hal ini sejalan dengan pernyataan Kaya (2018) dimana nitrogen sangat berperan terhadap pertumbuhan tanaman padi.

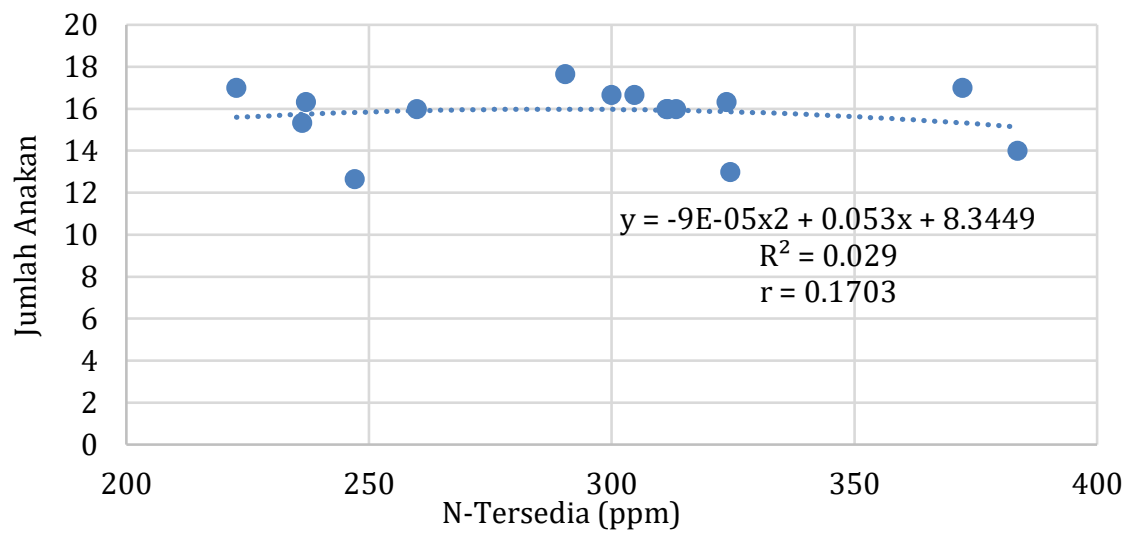

Gambar 7 Hubungan antara N-Tersedia dengan Jumlah Anakan Padi 


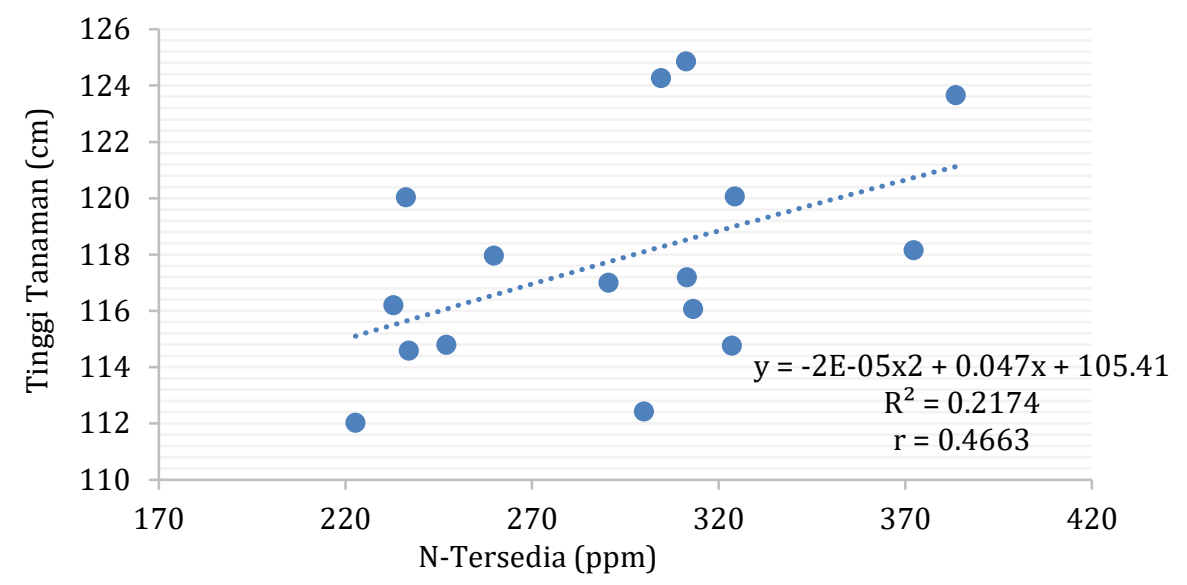

Gambar 8 Hubungan antara N-Tersedia dengan Tinggi Tanaman Padi

Peranan unsur $\mathrm{N}$ dalam tanaman yang terpenting adalah sebagai penyusun atau sebagai bahan dasar protein dan pembentukan klorofil karena itu $\mathrm{N}$ mempunyai fungsi membuat bagian-bagian tanaman menjadi lebih hijau, banyak mengandung butir-butir hijau dan yang terpenting dalam proses fotosintesis, mempercepat pertumbuhan tanaman yang dalam hal ini menambah tinggi tanaman dan jumlah anakan (Dobermann and Fairhust, 2000).

\section{KESIMPULAN}

Berdasarkan penelitian yang telah dilakukan, maka dapat diisimpulkan bahwa:

a. Aplikasi silika dan asam humat berpengaruh nyata terhadap ketersediaan nitrogen tanah berpasir

b. Dosis terbaik kombinasi silika dan asam humat terhadap ketersediaan nitrogen pada tanah berpasir yakni S2H3 (Silika 1 ton/ha dengan Asam humat $60 \mathrm{~kg} / \mathrm{ha}$ )

c. Kombinasi silika dengan asam humat tidak berpengaruh nyata pada tinggi tanaman padi, namun berpengaruh nyata pada jumlah anakan tanaman padi pada 2 MST.

\section{Ucapan terima kasih}

Kami ucapkan terima kasih kepada UPN Veteran Jawa Timur yang memberikan suproting dana untuk pelaksanaan penelitian melalui LPPM, dosen dan teman teman peminatan Sumber Daya Lahan Jurusan Agroteknologi Fakultas Pertanian, serta laboran SDL yang telah membantu analisa tanah dan tanaman.

\section{DAFTAR PUSTAKA}

Agung, G. F., Hanafie Sy, M. R., dan Mardina, P. 2013. Ekstraksi silika dari abu sekam padi dengan pelarut $\mathrm{KOH}$. Jurnal Konversi UNLAM 2 (1): 28-31.

Ali, M. dan Mindari, W. 2016. Effect of humic acid on soil chemical and physical characteristics of embankment. MATEC Web of Conferences, 58.

Balai Penelitian Tanah. 2009. Petunjuk Teknis Edisi 2 Analisis Kimia Tanah, Tanaman, Air, dan Pupuk. Balai Penelitian Tanah. Bogor.

Bijay, S., Yadvinder, S., Khind, C. S., dan Meelu, O. P. 1991. Leaching losses of urea-N applied to permeable soils under lowland rice. Fertilizer Research 28 (2): 179-184.

Coasne, B., Galarneau, A., Di Renzo, F., dan Pellenq, R. J. M. 2010. Molecular simulation of nitrogen adsorption in nanoporous silica. Langmuir 26 (13): 10872-10881.

Dobermann, A. dan T. Fairhust. 2000. Nutrient Disorders and Nutrient Management. Tham Sin Chee

Greger, M., Landberg, T., dan Vaculík, M. 2018. 
Silicon influences soil availability and accumulation of mineral nutrients in various plant species. Plants 7 (2): 116.

Hermanto, D., Dharmayani, N., Kurnianingsih, R., dan Kamali, S. 2013. Pengaruh asam humat sebagai pelengkap pupuk terhadap ketersediaan dan pengambilan nutrien pada tanaman jagung di lahan kering Kecamatan Bayan-NTB. Jurnal Ilmu Pertanian 16 (2): 28-41.

Kaya, E. 2018. Pengaruh kompos jerami dan pupuk NPK terhadap N-tersedia tanah, serapan-N, pertumbuhan, dan hasil padi sawah (Oryza sativa L). Agrologia 2 (1): 43-50.

Kristanto, B. A. 2018. Aplikasi silika untuk pengelolaan kesuburan tanah dan peningkatan produktivitas padi secara berkelanjutan. Prosiding Seminar Nasional Lingkungan, Ketahanan, Dan Keamanan Pangan Universitas Sebelas Maret. Surakarta. pp 102-109.

Liu, D., Huang, Z., Men, S., Huang, Z., Wang, C., dan Huang, Z. 2019. Nitrogen and phosphorus adsorption in aqueous solutions by humic acids from weathered coal: Isotherm, kinetics and thermodynamic analysis. Water Science and Technology 79 (11): 2175-2184.

Lumbanraja, P., dan Harahap, E. M. 2015. Perbaikan kapasitas pegang air dan kapasitas tukar kation tanah berpasir dengan aplikasi pupuk kandang pada ultisol Simalingkar. Jurnal Pertanian Tropik 2 (1): 53-67.

Mahmood, Y. A., Ahmed, F. W., Juma, S. S., dan Al-Arazah, A. A. A. 2019. Effect of solid and liquid organic fertilizer and spray with humic acid and nutrient uptake of nitrogen, phosphorus and potassium on Growth, Yield of Cauliflower. Plant Archives 19 (2): 1504-1509.

Nuraini, Y dan Zahro, A. 2020. Pengaruh aplikasi asam humat dan pupuk NPK Phonska 15-15-15 terhadap serapan nitrogen dan pertumbuhan tanaman padi serta residu nitrogen di lahan sawah. Jurnal Tanah dan Sumberdaya Lahan 7 (2): 195-200.

Nwite, J. C., Unagwu, B.O., Okolo, C. C., Igwe, C. A., dan Wakatsuki, T. 2019. Improving soil silicon and selected fertility status for rice production through rice-mill waste application in lowland sawah rice field of southeastern Nigeria. International Journal of Recycling of Organic Waste in Agriculture 8 (2): 271-279.

Patil, V. N., Pawar, R. B., Patil, A. A., dan Pharande, A. L. 2018. Influence of rice husk ash and bagasse ash as a source of silicon on growth, yield and nutrient uptake of rice Influence of rice husk ash and bagasse ash as a source of silicon on growth , yield and nutrient uptake of rice. International Journal of Chemical Studies 6 (1): 317-320.

Patti, P.S. Kaya, E dan Silahooy, C.H. 2013. Analisis status nitrogen tanah dalam kaitannya dengan serapan $\mathrm{N}$ oleh tanaman padi sawah di Desa Waimital, Kecamatan Kairatu, Kabupaten Seram Bagian Barat. Jurnal Agrologia 2 (1): 51-58.

Peres, E. C., Favarin, N., Slaviero, J., Almeida, A. R. F., Enders, M. P., Muller, E. I., dan Dotto, G. L. 2018. Bio-nanosilica obtained from rice husk using ultrasound and its potential for dye removal. Materials Letters 231 (2): 72-75.

Plhák, F. 2003. Nitrogen supply through transpiration mass flow can limit nitrogen nutrition of plants. Plant, Soil and Environment, 49 (10): 473479.

Singh, A. K., Singh, R., dan Singh, K. 2005. Growth, yield and economics of rice (Oryza sativa) as influenced by level and time of silicon application. Indian Journal of Agronomy 50 (3): 190193.

Sivakumar, K. 2007. Effect of humic acid on the yield and nutrient uptake of rice. Oryza 44 (3): 277-279. 
Stevenson, F. J. 1994. Humus Chemistry: Genesis, Composition, Reactions - F. J. Stevenson - Google Books (2nd ed.). Wiley Publisher.

Suntari, R., Retnowati, R., dan Munir, M. 2013. Study on the release of $\mathrm{N}$-available $\left(\mathrm{NH}_{4}{ }^{+}\right.$and $\left.\mathrm{NO}_{3}{ }^{-}\right)$. International Journal of Agriculture and Forestry 3 (6): 209-219.

Tunjung Sari, P., dan Ali Arifandi, J. 2019. Pengaruh senyawa humat dan pupuk kandang ayam terhadap serapan hara nitrogen dan kualitas bibit stek ubi jalar. Jurnal Bioindustri 1 (2): 8397.

Vermoesen, A., Van Cleemput, O., dan Hofman, G. 1993. Nitrogen loss processes: mechanisms and importance. Societe Belge de Pedologie. 43(3): 417-433.

Wahid, A. S. 2003. Peningkatan efisiensi pupuk nitrogen pada padi sawah dengan metode bagan warna daun. Agrohorti 7 (3): 156-161.

Yu, H., Xie, B., Khan, R., dan Shen, G. 2019. The changes in carbon, nitrogen components and humic substances during organic-inorganic aerobic cocomposting. Bioresource Technology 271 (3): 228-235. 